

Volume 3 | Issue 2 | 2018

\title{
New Urbanism, Gentrification, and Social Justice in Tysons, Virginia
}

\author{
Catherine Overberg and Johnny Finn, PhD \\ Christopher Newport University \\ Virginia Zeta Chapter
}

Vol. 3(2), 2018

Title: New Urbanism, Gentrification, and Social Justice in Tysons, Virginia

DOI:

ISSN: $2381-800 \mathrm{X}$

Keywords: Gentrification, Production, Consumption, New Urbanism

This work is licensed under a Creative Commons Attribution 4.0 International License.

Author contact information is available from tlindblom@alphachihonor.org or kvosevich@alphachihonor.org

\section{Aletheia-The Alpha Chi Journal of Undergraduate Scholarship}

- This publication is an online, peer-reviewed, interdisciplinary undergraduate journal, whose mission is to promote high quality research and scholarship among undergraduates by showcasing exemplary work.

- Submissions can be in any basic or applied field of study, including the physical and life sciences, the social sciences, the humanities, education, engineering, and the arts.

- Publication in Aletheia will recognize students who excel academically and foster mentor/mentee relationships between faculty and students.

- In keeping with the strong tradition of student involvement in all levels of Alpha Chi, the journal will also provide a forum for students to become actively involved in the writing, peer review, and publication process.

- More information can be found at www.alphachihonor.org/aletheia. Questions to the editors may be directed to tlindblom@alphachihonor.org or kvosevich@alphachihonor.org.

\footnotetext{
Alpha Chi is a national college honor society that admits students from all academic disciplines, with membership limited to the top 10 percent of an institution's juniors, seniors, and graduate students. Invitation to membership comes only through an institutional chapter. A college seeking a chapter must grant baccalaureate degrees and be regionally accredited. Some 300 chapters, located in almost every state, induct approximately 11,000 members annually. Alpha Chi members have been "making scholarship effective for good" since 1922.
} 


\title{
New Urbanism, Gentrification, and Social Justice in Tysons, Virginia
}

\author{
Catherine Overberg \\ Christopher Newport University \\ Virginia Zeta
}

\begin{abstract}
Fairfax County, Virginia's use of New Urbanist principles to redevelop Tysons, Virginia, aligns with both the production- and consumption-side theories of gentrification. Through interviews with business owners, residents, and government officials, we explore and analyze Fairfax County's New Urbanist plans and the community's reception of them. After analyzing this data and gentrification literature, we conclude that New Urbanist building policies do not support a diverse business environment and contribute to a gentrification of large-scale retail businesses. The county leveraged voluntary taxes onto developers, who passed these tax burdens onto the landlords, who increased their rental rates, causing their tenants to increase prices. Consumers, therefore, paid the taxes meant for developers. With Tysons as a case study, New Urbanist landscapes lead to the gentrification of small businesses, especially those unbecoming to the remodeled urban landscape.
\end{abstract}

Keywords: Gentrification, Production, Consumption, New Urbanism

\section{Introduction}

Tysons, Virginia, is a dynamic place, having evolved from suburb to edge city to emerging urban center all within the past forty years (Garreau, 2011). It is a majority white, highly-educated and affluent census-designated place equidistant to Dulles International Airport to the west and Ronald Reagan Washington National Airport to the southeast ("United States Census Bureau American FactFinder," 2018). Seeking a permanent form, Fairfax County, which governs the unincorporated area of Tysons, is restructuring the area according to the principles of New Urbanism - an urban architectural philosophy emphasizing walkability, mixed-use buildings, and diverse job opportunities (Ellis, 2002). This is all an effort to urbanize Tysons and combat the suburban sprawl so ubiquitous throughout the region. These efforts offer us an opportunity to examine the relationship between New Urbanism and gentrification through a case study of Tysons. Fairfax County hopes New Urbanism is the remedy to sprawl-induced problems impeding Tysons from becoming, as signs entering the area declare, "America's Next Great City."

We begin this article analyzing three theoretical/ conceptual areas that are directly relevant to Tysons's urban development: New Urbanism, gentrification, and the sociological concept of structure/agency. With this foundation, we describe our research methods and detail Tysons' history and evolving identity. In the discussion section we analyze Tyson's urban development in terms 
of the theoretical bodies presented above, with special attention paid to how this urban development impacts current and future residents, businesses, and transportation. Finally, we conclude by contextualizing what all this means for Tysons' future, as well as future cities facing New Urbanism and gentrification.

\section{Theorizing Gentrification and New Urbanism}

New Urbanism is an urban architectural philosophy emphasizing walkability, mixed-use buildings, and diverse job opportunities (Ellis, 2002). New Urbanism's popularity stems from governments, developers, and citizens alike wanting to rework their suburban spaces into a more functional place. The Congress for the New Urbanism (CNU) states:

neighborhoods should be diverse in use and population; communities should be designed for the pedestrian and transit as well as the car; cities and towns should be shaped by physically defined and universally accessible public spaces and community institutions; urban places should be framed by architecture and landscape design that celebrate local history, climate, ecology, and building practice. (Congress for the New Urbanism, 2017, para. 3)

Founding New Urbanist researchers Andres Duany, Elizabeth Plater-Zyberk, and Jeff Speck (2001) established these ideas, and more, within the Charter of New Urbanism, a list of minimum goals for cities and towns implementing New Urbanism. New Urbanists advocate that changing the physical structure of the neighborhood will change the way those neighbors interact with each other and how they spend their money, often benefitting the area (Knaap \& Talen, 2005). New Urbanism's work toward diversity spans beyond the aesthetic to achieve diversity and equality with people and neighborhoods.

Kentlands, Maryland, is one of the original examples of New Urbanist urban planning in the United States. Duany and Plater-Zybeck designed Kentlands with minimal cul-de-sacs, hidden garages, mixed-use buildings, and public park spaces (Kim, 2007). Kentlands' varied housing (apartments, condominiums, townhouses, detached single-family homes) resulted in a mix of residents (Kim, 2007). These built structures - porches, grid layouts, and open spaces - led residents to feel a tighter bond with the community (Lewis, 2014).

There is not a strong link between New Urbanism and gentrification throughout much of the academic lit- erature that addresses either concept. That said, we argue that many urban improvements associated with New Urbanism have the potential to result in gentrification. Changes such as eased access to transit can increase property taxes, home values, and rents and change the social make-up of an area, hallmarks of gentrification (Pyatok, 2000). The link between New Urbanism and gentrification is too strong to neglect.

Most theoretical engagements with gentrification pit two theoretical explanations - production-side and consumption-side - against each other. Proponents of each assert the supremacy of one or the other for explaining gentrification in any given city. However, for our analysis, we find it more fruitful to consider how both production- and consumptions-side explanations of gentrification can help to formulate a more complete understanding of how these processes have unfolded in Tysons.

Gentrification occurs when middle-class people move to inner cities and displace working-class residents. British sociologist Ruth Glass (1964) first coined the term gentrification as:

One by one, many of the working-class quarters in London have been invaded by the middle-classes upper and lower . . . once this process of 'gentrification' starts in a district it goes rapidly until all or most of the original working-class occupiers are displaced and the whole social character of the district is changed. (p. xviii)

Gentrification is the culmination of the increased purchasing power of the middle class, a desire for shorter commutes, and a greater ability to afford life in a city center. Overall, it represents the shifting global economy from industrial and manufacturing to a service-based economy.

Scholars using a production-side theory describe gentrification as a tool for production and profit, as another revenue stream for a city (Smith, 2002). The key players in production-side gentrification are local governments and real estate developers. These powerful entities control the urban landscape and benefit the most from profits generated by and for the city. Government involvement in gentrification often mitigates the potential risks of redevelopment associated with such major change (Hackworth, 2002). This involvement can come in the form of tax breaks to developers or altered zoning ordinances, where local governments relax zoning laws or building codes to encourage gentrification (Hack- 
worth, 2002). A government's involvement in these policies directly affects the pending development and results in production-side gentrification.

Smith (1987) pins down production-side gentrification to five causes: falling profit and a cyclical movement of profit, the rent gap, deindustrialization, spatial centralization paired with a decentralization of capital, and changing demographic and consumption patterns. First, according to Smith (2002), production-side theory represents a price difference between capital investments and opportunities for reinvestment. New Urbanism is, therefore, a tool for capitalist growth. Cities act as sponges, absorbing businesses' excess profits and satisfying the city's need for investment and the businesses' need to reinvest their profits. Governments and developers, seeking more profits for the city and their business, recruit more profitable businesses able to reinvest in the city.

The city as a site of reinvestment is, in part, funded by businesses reinvesting their profits (Harvey, 2015). It becomes a mutually beneficial relationship, where the business' profits grow along with the city, shaped in accordance with the interests the business holds in the city (Harvey, 2015). The most powerful rights in gentrified cities are those reserved for private property, rather than those for the individual. Governments and developers often regenerate cities through New Urbanism because of the dual influence of New Urbanism's and gentrification's abilities to produce profitable returns on capital investments (Smith, 2002).

The second component concerns the rent gap - the difference in value between a property's capitalized rent (or contract rent) and potential land rent (Clark, 1995). Gentrification is most likely to occur in locales with a significant difference between capitalized and potential land rents, reflecting the largest potential profit margin for developers (Smith, 1979). Investors reverse the devaluation of the building by investing in its potential (Weber, 2002). Initially, a land's capitalized and potential rents are the same; however, over time, the potential land rent increases due to a more intense use of the land (Lopez-Morales, 2011). An area's land values increase due to economic, physical, and/or social upgrading (Marcuse, 2015). Location obviously plays a major role in land value, as improved accessibility and transportation increase the use, and, therefore, the value, of that land (Hammel, 1999). Buildings more susceptible to gentrification by way of the rent gap are older buildings located near new transportation networks, creating a large disparity between the current rent and the rent at its "highest and best" use (Smith, 1979).

Third, deindustrialization reflects a global economic shift from an industrial-based to a service-based economy (Curran, 2004). This increases the size of the middle class, whose growing power will be discussed in the consumption-side description of gentrification (Ley, 1996). The depreciation of land and buildings as a result of the deindustrialization of urban cores only increased their potential for urban renewal. Gentrification has taken advantage of fewer manufacturing jobs in urban areas and the decreasing size and power of working class neighborhoods and residents, respectively (Curran, 2004).

Throughout this explanation of production-side gentrification, it should be clear the motive is capital accumulation, rather than social regeneration. Production-side gentrification theorists explain gentrification through the rent-gap theory, uneven capital investment, and potential profits (Slater, 2011). What is not included in these descriptions is the cultural aspect inherent in every city, which itself is a highlight of consumption-side theorizations of gentrification.

Changing demographics at all ranges of the age spectrum influence gentrification. Young urban people, often called yuppies, are an increasingly college-educated population and produce smaller family units, leaving them more able to live in a city center (Fyfe \& Kenny, 2005). Additionally, many of these yuppies fall into the Millennial generation, who generally have a decreased desire and ability to reside in the suburbs, partly due to their reliance on student loans, causing an inability to afford a mortgage (Houle \& Berger, 2015). For the Baby Boomer generation, many migrate to the city because of a more independent family and ability to lead an easier urban life in retirement (Fyfe \& Kenny, 2005).

Consumption-side theory proposes a cultural explanation of gentrification, focusing on the individual gentrifiers themselves, rather than the broader economic structures (Smith, 2002). Gentrifiers are typically understood to be middle-class individuals who initiate gentrification in a city to fit their lifestyle (Smith, 1992). Often described as yuppies, middle-class, and upwardly mobile, with few or no children, gentrifiers seek affordable housing in working-class neighborhoods (Johnston \& Sidaway, 2015; Lees, Wyly, \& Slater, 2010). This allows them to lead a city life at an affordable price, an increasingly rare opportunity. If gentrifiers purchase, rather than rent, in a working-class neighborhood, they are 
able to build equity and solidify their middle-class status (Tonkiss, 2005). Gentrification, therefore, changes the demographics and population of a city, often reflected in changing retail (Zukin et al., 2009). Gone are mom-andpop shops and community watering holes, replaced by boutique stores and craft breweries.

There is a major effort within consumption-side theory to understand and explain a new middle-class habitus. Breaking down the term, the new middle-class is similar to a creative class, comprised of individuals who desire distinction from their counterparts (Bridge, 2001). Instead of using their economic capital, which their peers amassed more of, the new middle-class uses their cultural capital to express their style and stability in urban spaces (Bridge, 2001). A habitus is how an individual styles his or her life based on the influences and aesthetics in his or her environment (Ley, 2003). Taken as a whole, the new middle-class and their ideals and practices create a gentrification habitus, a means of solidifying their own social class in a unique fashion (Bourdieu, 2018). Gentrifiers, then, are individuals using their agency to establish and solidify their cultural, rather than economic, power.

We argue that the explanatory factors of gentrification are not singular in nature. Consumption-side forces pair with production-side forces to ultimately create ur- ban change (Smith, 1986). While these forces do not exert themselves equally, they are nonetheless both at play (Smith, 1986). Inequalities in cities manifested through gentrification are the result of both production- and consumption-side forces and must be understood in tandem to fully understand and account for the inequality (Ley, 2003). Both forces of gentrification result in changes to a city and must, therefore, be understood in relation to one another, rather than in opposition (Smith, 1986).

This theoretical discussion of gentrification broadly fits into the sociological debates surrounding structure and agency. Simply put, agency refers to individuals' ability to freely make decisions, while structure refers both to the material and cultural structures that constrain individual agency (Sewell Jr., 1992). According to Anthony Giddens (1984), structure and agency work in cooperation with each other because the resources, rules, and ideas of agents depend on and simultaneously reinforce social structures.

Generally speaking, production-side explanations of gentrification focus on the primacy of economic and legal structures in explaining the processes of gentrification. Governments and developers create economic, legal, and material structures that limit and constrain the individual agency of residents. Developers incentivize businesses they believe will be profitable, putting citi-

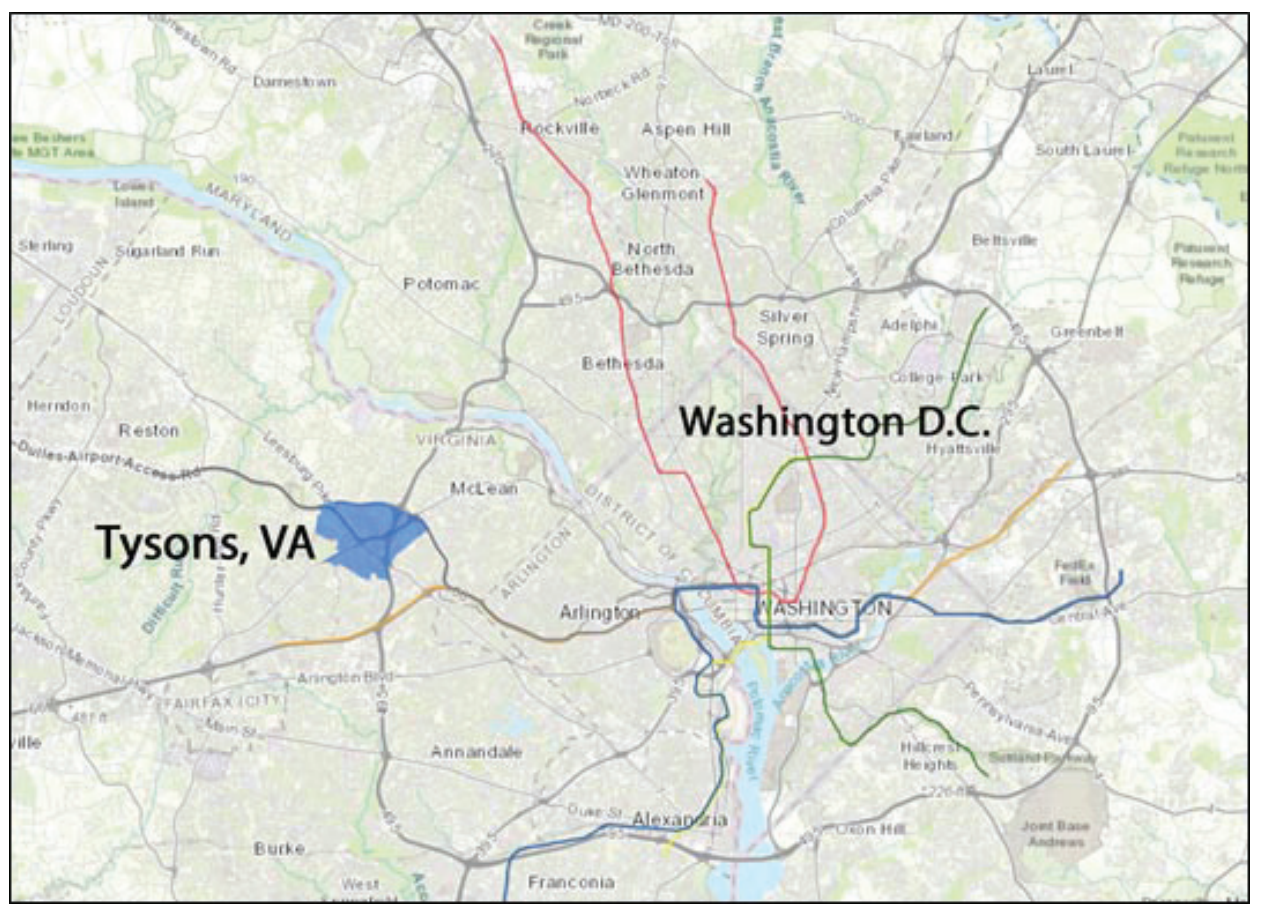

Figure 1 - Transportation map of Tysons. Map by authors (2018). 
zens on the receiving end of the urban changes. On the other hand, consumption-side explanations of gentrification focus more on the individual agency of gentrifiers, as they are seen as the drivers of the gentrification process, although they are, of course, not immune from the very political, economic, and legal structures articulated in production-side explanations.

The interplay between structure and agency as it plays out in gentrification is perhaps most visible in changes to the retail landscape of gentrifying neighborhoods and cities. On the one hand, production-side explanations can easily explain the structural economic and legal forces that would lay the groundwork for retail turnover, especially in areas with a high rent gap due in part to the widespread deindustrialization of urban economies since the 1970s. On the other hand, the individual and specific consumer tastes of "yuppie gentrifiers" help to explain the particular nature of retail turnover (Smith \& Williams, 2007).

\section{Situating Tysons}

In a certain way, Tysons is an anomaly: a suburban location with urban/city qualities. Therefore, while suburbs are currently growing faster than cities, Tysons benefits by having aspects of both (Frey, 2018). No matter the reason or age of those moving to cities, the cultural balance of cities skews more toward these new interests than those existing in the city. In order to fully understand the ongoing urban transformation of Tysons, Virginia, over the last several decades, it is vital to engage with theoretical contributions that come from the vast literatures on both gentrification and New Urbanism. Though often not considered together, the specific case of Tysons, Virginia, opens up new avenues for intersectional analysis. It is to that specific case that we now turn.

Tysons' location primed the former farming area to transform to a suburb due to key post-World War II elements. In 1961, the Central Intelligence Agency opened four miles away in McLean, Virginia, bringing contractors looking for office space (O'Connell, 2011). As the U.S. Department of Defense budget expanded throughout the mid-to-late $20^{\text {th }}$ century, more contractors arrived, forcing the area to accommodate the influx of companies and their employees (O'Connell, 2011). Dulles International Airport opened in 1962 in Sterling, Virginia, about fourteen miles west of Tysons (O'Con- nell, 2011). The completion of the Capital Beltway, a highway circumventing the Washington, DC, area, in 1964 centered all 1,700 acres of Tysons around Routes 7, 123 , and Interstate 495, resulting in extensive highway access (see Figure 1, Ceruzzi, 2000).

Like Tysons, suburbs grew, in large part, because of the affordability of the automobile after World War II (Nijman \& Clery, 2015). Coupled with a demographic shift and culturally-driven desire to leave cities, suburbs across the United States tripled in population from 1950 to 1980 (Nijman \& Clery, 2015). As suburbs increased in size, they were maintained as overwhelmingly white spaces (Rothstein, 2017; Wiese, 2005). The inner city decay brought on by a combination of deindustrialization and white suburbanization further perpetuated white flight, as suburbs offered a respite from the deindustrializing urban core for white Americans (Nijman \& Cleary, 2015). The specific case of Tysons, and Fairfax County more broadly, was no different, as whites largely benefited from suburbanization of northern Virginia as an escape for Washingtonians (Shihadeh \& Ousey, 1996).

Tysons Corner Center and Tysons Galleria, the area's shopping landmarks, opened in 1968 and 1988, respectively (Ceruzzi, 2000). The importance of these malls to the region cannot be overstated. Both anchored Tysons when nothing else could, when area residents knew Tysons only for its malls. These malls, despite the arrival of new retailers and attractions, continue to be Tysons' landmarks. Today, Tysons Corner Center has more than three hundred stores and restaurants in 2.4 million square feet, making it the tenth-largest mall in the United States (Fairfax County Economic Development Authority, 2015). Tysons Galleria, its luxury counterpart across the street, has more than one hundred stores such as Cartier, Gucci, and Louis Vuitton, as well as various high-end restaurants (Fairfax County Economic Development Authority, 2015). One of Tysons' four Silver Line Metro stops sits between these two malls, featuring a bridge directly linking the Metro and Tysons Corner Center. These malls continue to anchor Tysons and remain the centerpiece of an emerging urban area.

Along with housing and commerce, employers also moved jobs outside of Washington, DC. In 1910, Congress passed the Height of Buildings Act, limiting residential building heights to 90 feet and commercial zones to 130 feet in Washington, DC, with some exceptions 
(Fogle, 2018). This imposed a permanent premium on office space in the District. Fairfax County accommodated the influx of companies and their corresponding office buildings in Tysons by boasting cheap rents and easy access to Washington, DC, the Pentagon, and Dulles International Airport. Today, Tysons is home to over 100,000 jobs and five Fortune 500 companies: TEGNA, Hilton Worldwide, Capital One Financial, Freddie Mac, and Booz Allen Hamilton.

Thus, throughout the $20^{\text {th }}$ century, Tysons was transformed from a rural community into an overgrown office park. Today, buildings sit far apart, separated by car dealerships, expansive parking lots, and streets that do not appeal to pedestrians. Tysons was an afterthought for those not working or shopping there, but Fairfax County is seeking to put Tysons at the forefront of the minds of residents and business owners.

In 2010, Fairfax County's Board of Supervisors passed the Tysons Comprehensive Plan. In it, the County planned for improved transportation networks, neighborhood development, and public space. While the Board of Supervisors never said as much, these are all hallmarks of New Urbanism (Congress for New Urbanism, 2017). The original plan called for Tysons to hold 200,000 jobs and 100,000 residents, drastic increases when compared to the 2010 numbers of 105,000 jobs and 17,000 residents (Census, 2017). It also established goals of becoming a green city, with energy-efficient buildings, park spaces, and trails. Supporting this green philosophy, the Board of Supervisors vowed to design transportation networks to better accommodate bikes, buses, pedestrians, and limit cars in an already congested area. Tysons would also be redistricted to prioritize transit-oriented development (TOD), with 75 percent of all development occurring within a half-mile of one of the four planned Metro stations. Of Tysons' eight new districts, the Board of Supervisors established four specifically for TOD (Fairfax County Board of Supervisors, 2010).

In accordance with TOD, Fairfax County launched the Silver Line extension of the Metro rail line into Tysons in 2014. Tysons now has four Metro train stops: Spring Hill, Greensboro, Tysons Corner Center, and McLean, as shown in Figure 2. As the Silver Line expands to reach Dulles International Airport by 2020, Tysons will be the midpoint between Washington, DC, and Dulles International Airport.

With all this recent change, Tysons is also suffering from an identity crisis as it attempts to shed its suburb title. Formerly "Tysons Corner," it is now just "Tysons"

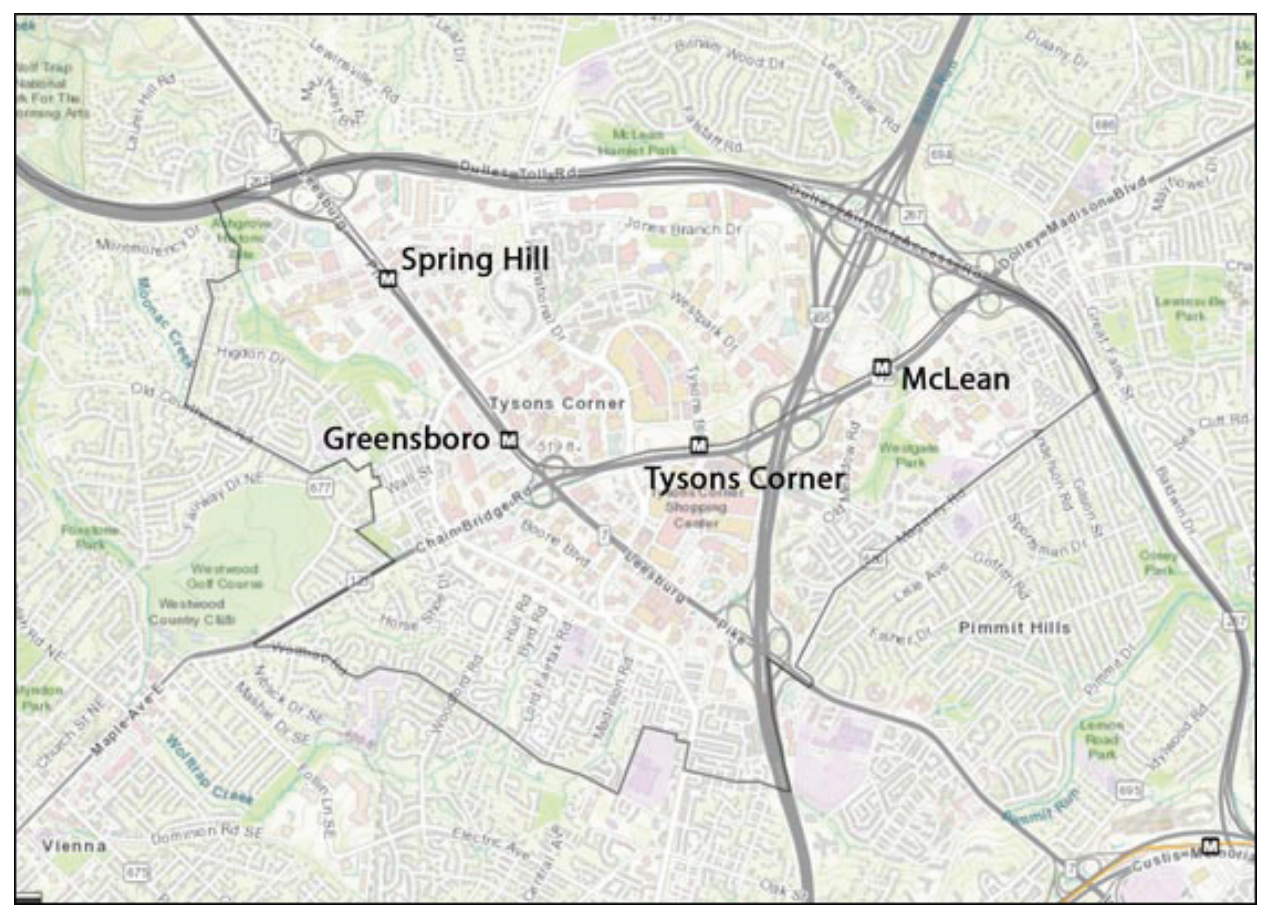

Figure 2 - Map of Silver Line Metro through Tysons. Map by authors (2018). 
after the United States Census Bureau agreed to change the area's name (Connolly, 2015). According to Representative Gerry Connolly, who represents Virginia's $11^{\text {th }}$ district, which includes Tysons, no legitimate city can have "corner" in the name; it lessens the impact of its potential restructuring and rebranding efforts (Connolly, 2015). Despite this change, highway signs leading to the area call it "Tysons Corner." Longtime residents call it Tysons Corner, while new residents call it Tysons. Businesses in the Tysons city district use McLean, Vienna, Tyson's Corner, Tysons Corner, or Tysons to describe their similar locations.

In this case study, we found it beneficial to use qualitative methods to discuss gentrification, offering the most comprehensive view of Tysons. Tysons is a complex locale, made even more complex in its transformation from suburb to city within a generation. While not explicitly stated in Fairfax County's Comprehensive Plan for the area, Tysons' remodel centers around New Urbanist ideals: improved transit networks, transit-oriented development, and mixed-use developments. New Urbanism is, therefore, our lens to study gentrification in Tysons. While New Urbanism is evident in Tysons, gentrification is more obscure.

\section{Methods}

We collected qualitative data to answer our research questions: How intertwined are New Urbanist landscapes and gentrification, and what is the future of this relationship based on the current state of Tysons? We conducted historical/archival analysis, landscape observation and analysis, and qualitative field research. We completed the National Institutions of Health's Institutional Review Board (IRB) Protecting Human Research Participants online training through Christopher Newport University, and each of the eleven participants agreed to be recorded for research purposes. Each interview, either over the phone or in-person, lasted between thirty and forty-five minutes. In order to ensure a diverse set of participants, we employed snowball sampling, beginning from our own social and professional contacts (Taylor, Bogdan, \& DeVault, 2015). From these initial contacts, we were able to interview eight additional participants (Biernacki \& Waldorf, 1981). Our eleven interview participants included a local real estate agent and lifelong resident of Tysons, an employee of the Tysons Partnership, two small business owners, two Fairfax
County employees involved in the planning of Tysons, a homeowners' association president and sixteen-year resident, an employee of a company headquartered in Tysons and resident, an employee of the Northern Virginia Chamber of Commerce, retiree and lifelong resident, and a civil engineer and resident.

While we tailored each interview to the participant and his or her background, one question remained the same: Why do you believe Fairfax County wanted to urbanize Tysons? A summative content analysis of secondary resources, such as fliers, advertisements, and urban plans obtained at the Tysons Partnership Open House bolstered our analysis (Hsieh \& Shannon, 2005; Myers, 1997). We transcribed each interview and coded it based on relevant themes. We used Dedoose, an online qualitative analysis software, to organize and code these interviews and other relevant media.

\section{Discussion}

We sought to examine the interplay between New Urbanism and gentrification through a case study analysis of Tysons, Virginia. Through our research, we arrived at four conclusions. First, Fairfax County's implementation of a production-side gentrification policy by way of their Comprehensive Plan has created a surplus of development. Since 2014, Tysons' skyline has seen the addition of 4.2 million square feet of residential, office, retail, and hotel space and awaits 40 million more square feet of development already approved by the Fairfax County Board of Supervisors (Tysons Partnership, 2017). While there is plenty of space for residents and offices, supply is greatly outpacing demand, evidenced in numerous partially occupied residential and office buildings.

However, what is more telling is that, despite the surplus of such spaces, the rental and purchase rates have not decreased to reflect the macroeconomic "law" of supply and demand. This is in part due to Tysons' budding image - publicly reducing prices now would negatively impact an area trying to recruit new residents at top dollar. Tysons was already an expensive place to live and work, with a median income of $\$ 100,745$ in 2016 (Census, 2017). Even residents who only moved to the area a few years ago reflected how they would be unable to afford their home in Tysons today. This is partially explained by Tysons' image resulting in sticker shock for new residents. For residents who arrived as 
recently as 2017 , it was not uncommon for landlords to offer a few months of free rent up front. This temporarily reduces the price without publicizing it as such, allowing landlords to avoid a negative impact on their building's "luxury" status. The disconnect between the advertised and paid rent likely will not last but is contingent on Tysons increasing its residential population in its new properties.

Second, showing the duality of production- and consumption-side gentrification, Tysons is selling a luxurious lifestyle as much as they are selling a place. Apartment buildings boast such amenities as dog spas, rooftop pools, floor-to-ceiling windows, and soaking tubs. These amenities attract a certain population to the area. However, businesses unbecoming to the newly urban, luxurious Tysons are gradually being pushed out either through increased rental rates or changing consumer tastes, reflecting the pairing of both productionand consumption-side theories. For instance, Tysons Biergarten replaced a sex toy and porn video shop. VITA Apartments and Intelsat's administrative headquarters, each featuring an upscale restaurant on the ground floor of a mixed-use complex, replaced a small strip mall containing an office supply store, nail salon, and Circuit City. The Fairfax County Board of Supervisors rezoned an area adjacent to the Spring Hill Metro currently housing car dealerships to make room for 150- to 400-foot-tall mixed-use developments. Much of this retail revitalization originates from zoning outlined in the Comprehensive Plan; however, the businesses that come to Tysons largely reflect the population and its lifestyle.

For service-based businesses coming to Tysons, such as small retail stores and fast-food chains, their employees likely cannot afford to live in Tysons. The Comprehensive Plan requires every residential structure offer twenty-percent of its units as "affordable housing." Fairfax County stipulates those eligible for affordable housing make between 50 and 120 percent of the median income (Fairfax County, 2010). With a median income of $\$ 100,745$, residents making anywhere between $\$ 50,372.50$ and $\$ 120,894.00$ are eligible for affordable housing (Census, 2017). For an area pitching "live where you work," only certain populations can afford to do so, likely excluding teachers, police officers, fire fighters, and restaurant employees (Fairfax County Board of Supervisors, 2010). One small business owner noted the challenge of hiring for these lower- to middle-income brackets, as employees commute to Tysons from more affordable areas of the Washington, DC,
Metro region. After time, this long and expensive Metro commute takes its toll, and employees leave for jobs closer to where they can afford to live.

This is not the only burden small business owners in Tysons face. In what seemed like a good idea at the time, Fairfax County levied a tax on real estate developers to help fund Metro's Silver Line, thereby alleviating the tax burden from the people. However, through the leasing structure, developers passed this tax burden onto their landlords, who then passed it onto their tenants. Many tenants had to increase their prices to pay for the tax originally meant for developers. Therefore, consumers still paid the tax through increased prices, probably not what Fairfax County had in mind when implementing the tax. This tax burden was unique because small businesses and their customers faced the brunt of it, while national chains and large businesses were less likely to increase prices due to a more substantial financial cushion.

Third, New Urbanist construction in a new urban center does not bode well for existing businesses requiring a large amount of square-footage. Mixed-use buildings are meant to accommodate numerous small square-footage stores, not one massive store. Furniture stores, car dealerships, department stores, auto repair shops, and even office supply stores currently in Tysons do not fit the County's vision for an urban future (González \& Waley, 2013). As noted earlier, gentrification of large-scale retail businesses has already begun through Fairfax County's rezoning of the areas surrounding Tysons' four Metro stops (Fairfax County Board of Supervisors, 2010). TOD, as well as Fairfax County's adoption of a bulls-eye development design placing the densest development adjacent to the Metro stops, forces otherwise stable and profitable businesses to move elsewhere or close completely. Gentrified businesses are often stores requiring a large retail footprint and/or small businesses lacking the support of a national chain. As these large retail businesses and their employees leave Tysons, new businesses better fit for the urban environment arrive. These come in the form of urban small businesses, such as the Tysons Biergarten, as well as national chains able to survive amidst potentially unstable urbanization.

Finally, turning to focus on residents, those who have lived in the area for more than fifteen years reflect unease in the changing environment. Once thought to be living in the suburbs, these residents are newly urban dwellers. While the Silver Line affords these residents 
access to the Washington, DC, Metro area, it also brings the Washington, DC, Metro area to Tysons. In our interviews, some residents said they were not fond of what they perceive to be an increase of homeless people sitting on sidewalks asking for money, or the decreasing neighborliness due to the changing population. However, these residents are cognizant of the pros of the Silver Line's impact on traffic and seem to think it worth the improved transportation networks reducing commute times in the area.

Younger residents, in both age and time in the area, reflect an optimistic impatience about Tysons. They are eager for walkable markets, retail, and trails but feel they suffered through enough years of construction and detours. The most direct impact and inconvenience on all residents has been the construction, which will not finish in the near future. In part due to their impending futures in the area, younger people see construction as a necessary evil, while longtime, older residents more so view it as just an evil causing more traffic.

A provision in the Comprehensive Plan laid the foundation for the Tysons Partnership, a public-private partnership and example of government policies controlling gentrification (Fairfax County Board of Supervisors, 2010). The Tysons Partnership functions to use "public funds or activities to foster private investment and development activity that might otherwise not occur" (Fairfax County Board of Supervisors, 2010, p. 19). By improving the public façade of Tysons, the area is more likely to receive private investments and fully achieve their goals. The Partnership seeks to create the urban identity through their status as a public-private partnership. Area businesses pay a membership fee, which the Partnership uses to host community events and business workshops. The Partnership's job, in the eyes of the County, is to create a community viable for private investment. Therefore, any community change initiated by the Partnership, while it might appear to be in line with the consumption-side theory, is really a production-side attempt by the County.

\section{Conclusion}

Tysons' progress from suburb to city is no small feat, and Fairfax County's work is not yet complete. The Comprehensive Plan plots Tysons' future to the year 2050, with periodic evaluations until then (Fairfax County Board of Supervisors, 2010). Therefore, the op- portunities for future research extend decades into the future. Continued research of New Urbanism and gentrification, both in theory and with Tysons in mind, will be necessary to understand Tysons' continued evolution.

The in-progress status of Tysons has presented a limitation to our research. Our research is a snapshot of Tysons, so even as we have aimed to provide as complete a picture as possible, Tysons is rapidly transforming and has even changed since we interviewed our participants. Our snowball sample centered around our respective social networks, meaning our interviews depended on our participants' social networks. Not all interview recommendations or schedules panned out, thereby limiting our data set. Another limitation was time, as we both managed other classes and coursework during this research process.

Tysons offers a unique opportunity to analyze production- and consumption-side gentrification while looking at New Urbanist influences. New Urbanist architecture will edge out existing large-scale businesses, replacing them with mixed-use buildings. Especially within a half-mile of Tysons' four Metro stops, otherwise viable and profitable small businesses could leave their locations for better rental rates elsewhere. As the Tysons Partnership works to solidify Tysons' reputation among private investors, it must work to develop a cohesive identity between residents, businesses, and visitors. 


\section{References}

Biernacki, P., \& Waldorf, D. (1981). Snowball sampling: Problems and techniques of chain referral sampling. Sociological Methods \& Research, 10(2), 141-163.

Bourdieu, P. (2018). Structures, habitus, practices. In Rethinking the Subject (pp. 31-45). Abingdon, United Kingdom: Routledge.

Bridge, G. (2001). Bourdieu, rational action and the timespace strategy of gentrification. Transactions of the Institute of British Geographers, 26(2), 205-216. Retrieved from http://www.jstor.org/stable/3650668

Ceruzzi, P. (2000). Tysons Corner, Virginia. Knowledge, Technology, \& Policy, 13(2), 86-102. doi:http://dx.doi. org/10.1007/s12130-000-1014-x

Clark, E. (1995). The rent gap re-examined. Urban Studies, 32(9), 1489-1503.

Congress for the New Urbanism. (2017, July 18). The Charter of the New Urbanism. Retrieved from https:// www.cnu.org/who-we-are/charter-new-urbanism

Curran, W. (2004). Gentrification and the nature of work: Exploring the links in Williamsburg, Brooklyn. Environment and Planning A, 36(7), 1243-1258. doi: 10.1068/a36240

Ellis, C. (2002). The new urbanism: Critiques and rebuttals. Journal of Urban Design, 7(3), 261-291. doi: $10.1080 / 1357480022000039330$

Fairfax County. (2010). Affordable and workforce housing. Fairfax County. Retrieved from http://www.fairfaxcounty.gov/tysons/housing/

Fairfax County Board of Supervisors. (2010, June 22). Fairfax County comprehensive plan, 2017 Edition. Retrieved from https://www.fairfaxcounty.gov/tysons/ sites/tysons/files/assets/documents/pdf/comprehensive plan/fc comp plan2017ed tysons amended04 04 2017.pdf

Fairfax County Economic Development Authority. (2015). Tysons Corner business area. Fairfax County Economic Development Authority. Retrieved from http://www. fairfaxcountyeda.org/tysons-corner-business-area

Fogle, J.M. (2018, March 28). Washington, DC. In Encyclopcedia Britannica online. Retrieved from https://www.britannica.com/place/Washington-DC\#ref1045745

Frey, W. (2018, May 29). Early decade big city growth continues to fall off, census shows. Brookings. Retrieved from https://www.brookings.edu/blog/the-avenue/2018/05/25/early-decade-big-city-growth-continues-to-fall-off-census-shows/

Fyfe, N. R., \& Kenny, J. T. (2005). The urban geography reader. London: Psychology Press.

Garreau, J. (2011). Edge city: Life on the new frontier. New York: Anchor.
Giddens, A. (1984). The constitution of society: Outline of the theory of structuration. Berkeley: University of California Press.

Glass, R. L. (1964). London: aspects of change (Vol. 3). London: MacGibbon \& Kee.

González, S., \& Waley, P. (2013). Traditional retail markets: The new gentrification frontier? Antipode, 45(4), 965-983. Retrieved from http://eprints.whiterose. ac.uk/77209/3/waleyp.pdf

Hackworth, J. (2002). Postrecession gentrification in New York city. Urban Affairs Review, 37(6), 815-843.

Hammel, D. J. (1999). Re-establishing the rent gap: An alternative view of capitalised land rent. Urban Studies, 36(8), 1283-1293. Retrieved from https:// search.proquest.com/docview/236263856/fulltextPDF/ 6DA2E70ED33540B8PQ/1?accountid=10100

Harvey, D. (2015). The right to the city. In LeGates R.T. and Stout F. (Eds.), The city reader, 6, (270-278). London: Routledge.

Houle, J. N., \& Berger, L. (2015). Is student loan debt discouraging homeownership among young adults? Social Service Review, 89(4), 589-621. doi: 10.1086/684587

Hsieh, H. F., \& Shannon, S. E. (2005). Three approaches to qualitative content analysis. Qualitative Health Research, 15(9), 1277-1288.

Kim, J. (2007). Perceiving and valuing sense of community in a New Urbanist development: A case study of Kentlands. Journal of Urban Design, 12(2), 203-230. doi:10.1080/13574800701306286

Lees, L., Wyly, E. K., \& Slater, T. (Eds.). (2010). The gentrification reader. London: Routledge.

Lewis, R. K. (2014, June 27). Kentlands, the Washington area's first community shaped by New Urbanism, turns 25. Retrieved from https://www.washingtonpost.com/ realestate/kentlands-the-washington-areas-first- community-shaped-by-new-urbanism-turns-25/2014/06/25/ 22ca30ae-f568-11e3-8aa9- dad2ec039789_story. $\mathrm{html}$ ?utm term $=$. ba44f293cce 7

Ley, D. (1996). The new middle class in Canadian central cities. In J. Caulfield and L. Peake (Eds.), City lives and city forms: Critical research and Canadian urbanism (pp. 15-32). Toronto: University of Toronto Press.

Ley, D. (2003). Artists, aestheticisation and the field of gentrification. Urban studies, 40(12), 2527-2544. doi: 10.1080/0042098032000136192

Lopez-Morales, E. (2011). Gentrification by ground rent dispossession: The shadows cast by large-scale urban renewal in Santiago de Chile. International Journal of Urban and Regional Research, 35(2), 330-357. doi: 10.1111/j.1468-2427.2010.00961.x

Marcuse, P. (2015). Gentrification. Social Justice and Personal Ethics. International Journal Of Urban And Regional Research, 39(6), 1263-1269. Retrieved from http://onlinelibrary.wiley.com/journal/10.1111/\%28ISSN\%291468-2427/issues. 
Myers, M. D. (1997). Qualitative research in information systems. Management Information Systems Quarterly, 21(2), 241-242.

Newman, K., \& Wyly, E. K. (2006). The right to stay put, revisited: Gentrification and resistance to displacement in New York City. Urban Studies, 43(1), 23-57. Retrieved from http://usj.sagepub.com/content/by/year

Nijman, J., \& Clery, T. (2015). Rethinking suburbia: A case study of metropolitan Miami. Environment and Planning A: Economy and Space, 47(1), 69-88.

O’Connell, J. (2017, October 09). Tysons Corner - darling of corporate America - passed over in Northern Virginia's pursuit of Amazon headquarters. Retrieved from https:// www.washingtonpost.com/news/digger/wp/2017/10/09/ tysons-corner-darling-of-corporate-america-passedover-in-northern-virginias-pursuit-of-amazon-headquarters/?utm_term $=.72$ eafc7c6b16

O’Connell, J. (2011, September 24). Tysons Corner: The building of an American city. The Washington Post. Retrieved from https://www.washingtonpost.com/ business/tysons-corner-the-building-of-an-americancity/2011/07/29/gIQAae2atK_story.html

Pyatok, M. (2000). Martha Steward vs. Studs Terkel? new urbanism and inner cities neighborhoods that work [speaking of places]. Places, 13(1). Retrieved from https:/escholarship.org/uc/item/2b67z1kn

Rothstein, R. (2017). The color of law: A forgotten history of how our government segregated America. New York: Liveright Publishing.

Sewell Jr., W. H. (1992). A theory of structure: Duality, agency, and transformation. American Journal of Sociology, 98(1), 1-29.

Shihadeh, E. S., \& Ousey, G. C. (1996). Metropolitan expansion and black social dislocation: The link between suburbanization and center-city crime. Social Forces, 75(2), 649-666. Retrieved from http://heinonline.org/HOL/ Page?handle $=$ hein.journals $/$ josf $75 \&$ div $=37 \& \mathrm{~g}$ sent $=1 \&$ casa_token $=\&$ collection $=$ journals

Slater, T. (2010). Missing Marcuse: On gentrification and displacement, City, 13:2-3, 292-311, doi: 10.108 $0 / 13604810902982250$

Slater, T. (2011). Gentrification of the city. The New Blackwell companion to the city, 1, 571-585. Retrieved from https://www.geos.ed.ac.uk/homes/tslater/gotcbridgewatson.pdf

Smith, N. (1979). Toward a theory of gentrification: A back to the city movement by capital, not people. Journal of the American Planning Association, 45(4), 538-548. doi: https://doi.org/10.1080/01944367908977002

Smith, N. (1986). Gentrification, the frontier and the restructuring of urban space. In N. Smith and P. Williams (Eds.), Gentrification of the city. London: Unwin Hyman.
Smith, N. (1987). Gentrification and the rentgap. Annals of the Association of American Geographers, 77(3), 462-5.

Smith, N. (1992). Blind Man's Bluff, or Hamnett's philosophical individualism in search of gentrification. Transactions of the Institute of British Geographers, 17(1), 110-115. doi:10.2307/622641

Smith, N. (2002). New globalism, new urbanism: Gentrification as global urban strategy. Antipode, 34: 427-450. doi:10.1111/1467-8330.00249

Smith, N. (2010). Uneven development: Nature, capital, and the production of space. Athens, Georgia: University of Georgia Press.

Smith, N., \& Williams, P. (Eds.). (2013). Gentrification of the City. London: Routledge.

Taylor, S. J., Bogdan, R., \& DeVault, M. (2015). Introduction to qualitative research methods: A guidebook and resource. Hoboken, NJ: John Wiley \& Sons.

Tonkiss, F. (2005). Space, the city and social theory: Social relations and urban forms. Cambridge: Polity.

Tysons Partnership. (2017). Construction pipeline. Retrieved from https://www.tysonspartnership.org/new-tysons/ future/.

United States Census Bureau American FactFinder. (2018). Tysons Corner CDP, Virginia. [Data set]. Retrieved from https://factfinder.census.gov/faces/nav/jsf/pages/ community facts.xhtml.

Weber, R. (2002). Extracting value from the city: Neoliberalism and urban redevelopment. Antipode, 34: 519-540. doi:10.1111/1467-8330.00253

Wiese, A. (2005). Places of their own: African American suburbanization in the twentieth century. Chicago: University of Chicago Press.

Zukin, S., Trujillo, V., Frase, P., Jackson, D., Recuber, T., \& Walker, A. (2009). New retail capital and neighborhood change: Boutiques and gentrification in New York City. City \& Community, 8: 47-64. doi:10.1111/j.15406040.2009.01269.x 